\title{
EFFORTS TO INCREASE ABILITY TO MAKE SOLUTIONS OF MATHEMATICAL STORIES THROUGH DISCOVERY LEARNING MODEL ON ELEMENTARY SCHOOL STUDENTS
}

\author{
Ressa Carera, Sita Ratnaningsih, Maifalinda Fatra
}

Islamic State University (UIN) Syarif Hidayatullah Jakarta

Email: carera46@gmail.com, sita@uinjkt.ac.id, maifalinda@uinjkt.ac.id

Naskah diterima : 19 Agustus 2017, direvisi : 21 September 2017 , disetujui : 29 September 2017

\begin{abstract}
This study to improve the ability to solve word math through discovery learning model in the elementary school students. This research method using Classroom Action Research method. The result showed that students' ability to solve word problems through a model of discovery learning has increased. Increase students ability to solve word problems can be seen in the first cycle obtained 68,6 and an average increase incycle II to 83,5 . Incerased ability to sove word problem are also characterized by increased activity of the students, the average of the first cycle of $70,8 \%$ of the student activity increased by $15,7 \%$ in the second cycle becomes $86,5 \%$. The positive response of student towards learning discovery learning model in the first $71,2 \%$, also an increase of $13,5 \%$ from $84,7 \%$ in the first cycle to second cycle.
\end{abstract}

Key Words: ability to solve math story problems, model discovery learning, elementary school students.

Pengutipan: Carera, Resa, Sita Ratnaningsih, \& Maifalinda Fatra. (2017). Efforts to Increase Ability to Make Solutions of Mathematical Stories Through Discovery Learning Model on Elementary School Students. JMIE: Journal of Madrasah Ibtidaiyah Education, 1(2), 2017, 180-187. jmie.v1i2.42. 


\section{INTRODUCTION}

This research is triggered by the low ability of students to solve the problem of IVC SDI grade story SDI Al Kautsar Bintaro. This can be seen from the student activity that is still confused if doing the given problem is different from the example and the students are confused in using which math strategy will be chosen. In addition, students are also still difficult to understand the language of mathematics to help in finding answers, and what happens students just guess the answer. When the researcher looks at the students' midterms, they look at the story of the students not using the steps they should take when completing the story. Most students mistakenly determine the strategy in solving the story. The student's answer is also directly to the final answer, without any known, asked, and concluded steps from the answer. According to Raharjo (2009), learning mathematics in schools, teachers should choose and use strategies, approaches, models, methods, and techniques that involve students actively in learning, both physically and socially. In learning mathematics students are brought toward observing, guessing, doing, trying, being able to answer the question why, and if possible argue. This principle of active learning is expected to foster the objective of creative and critical mathematics learning. The purpose in learning mathematics expect students to be able to understand the object of learning mathematics which means that students can understand every problem in mathematics and its completion not only with a requirement of ability but must with some ability that is to understand the concept, previous principle, and also understand the existing problem. Based on the books supporting mathematics lessons that refer to the current curriculum, many problems are found in the form of a matter of story on some of the subject matter. Susanto (2013). Many things in everyday life are closely related in the subject matter of mathematics. To facilitate students to master and understand the solution of mathematics problems, especially math problems form the story then the students must master the rules and formulas, besides that need to be accompanied by many intensity exercises working on the problem because if not accompanied by the exercise then the students will be difficult in achieving learning success. In this study described how the process of learning mathematics with discovery learning model in improving the ability to solve the problem of students' mathematical stories and responses and the level of student activity on learning mathematics with learning model Discovery. This research was conducted at Islamic Elementary School Al Kautsar Bintaro, in the academic year 2016-2017. The subjects of this study are IVC class students who became the subject of the study amounted to 20 people. The approach used in this study is a student centered approach, the students are more dominant in learning. Students find themselves solving the problems they face so that learning becomes more meaningful. Learning model used is discovery learning model.

The Discovery Learning model is defined as a learning process that occurs when the learner is not presented with the lesson in its final form, but is expected to organize itself. As Bruner argues, that: "Discovery Learning can be defined as the subject matter in the final form, but rather is required to organize it himself". Bruner's basic idea is Piaget's opinion that children should play an active role in classroom learning. (Dindin, 2015) Discovery learning model is one of the progressive teaching model and focuses on student activities in the learning process. Strictly speaking Amin in Risqi (2014) argues 
that a "discovery" activity is an activity or learning designed so that students can discover concepts and principles through their own mental processes. In this case the discovery occurs when the students in the mental process such as observing, classifying, making allegations, measuring, explaining, drawing conclusions and so forth to find some concepts or principles. Trianto (2015).

Biknell-Holmes and Hoffman in Slavin (2011) describe three characteristics of learning to discover: Exploring and solving problems for creating, combining, and generalizing knowledge, student-centered, activities to combine new knowledge and existing knowledge.

According to Syah in Dindin (2015) applying Discovery Learning in the classroom, there are several procedures that should be implemented in teaching and learning activities in general as follows: 1) Stimulation (Giving stimulus). First of all, at this stage students are faced with something that raises a question mark, then proceeds to not give generalizations, in order to arise desire to investigate itself, 2) Problem Statement (Statement / Problem Identification). After the next step of stimulation is the teacher gives the opportunity to students to identify as much as possible the agenda of the problems relevant to the lesson material, then one of them selected and formulated in the form of hypotheses (temporary answer to the problem question). 3) Data Collection (Data Collection). As the exploration takes place the teacher also gives the students the opportunity to gather as much relevant information as possible to prove whether or not the hypothesis is true. At this stage serves to answer questions or prove whether or not the hypothesis is true. 4) Data Processing (Data Processing). All reading information, interviews, observations, etc., are all processed, randomized, classified, tabulated, even if necessary calculated in a certain way and interpreted at a certain level of confidence. Data Processing is also called the coding / categorization that functions as the formation of concepts and generalizations. From these generalizations students will gain new knowledge about alternative answers / solutions that need to get a logical proof. At this stage students perform a careful examination to prove whether or not the hypothesis is set earlier with an alternative finding, related to the results of data processing. Based on the results of processing and interpretation, or existing information, statements or hypotheses that have been formulated earlier then checked, whether answered or not, proven or not. 5) Generalization (Interesting Conclusion). The stage of drawing a conclusion is the process of drawing a conclusion that can serve as a general principle and applies to all the same events or problems, taking into account the verification results. Based on the results of verification then formulated the principles underlying generalization.

With the application of discovery learning approach in learning has advantages. These benefits include: helping students to improve and improve cognitive skills and processes. Discovery is key in this process, depending on how it is learned. The knowledge gained through this model is highly personal and powerful because it reinforces understanding, memory and transfer, generating student pleasure, as the growing sense of investigation and success, centered on the students and the teacher's performances, is equally active in generating ideas. Even teachers can act as students, and as researchers in discussion situations, learning process situations become more aroused, students may learn by utilizing different types of learning resources. 
Besides having the advantages of this discovery learning model also has some disadvantages. Here are some of the weaknesses of the discovery learning model: it leads to the assumption that there is readiness of the mind to learn, inefficient to teach a large number of students, as it takes a long time to help them find other theories or problem solving, in some disciplines, to measure the ideas put forward by the students, does not provide opportunities for thinking to be found by students because it has been chosen first by the teacher. (Dindin, 2015) Solving problems is an activity in mathematics. This has become a characteristic of learning mathematics, students have to practice a lot of math problems. Exercise to solve problems can deepen the mastery of mathematical concepts while making students skilled in counting operations on each question. Even expected students can apply it in various problems encountered. Mathematical problems, especially with regard to everyday life such as: buying-buy, profitloss, time, distance, speed and so forth, often poured in the form of a story. About the story referred to in this study is a matter of mathematics presented in the form of stories and contents describe real problems in everyday life is intended so that students can feel learning mathematics that completion using mathematical skills from capability students. According to Winarni (2011), the story in mathematics is a matter that is presented in the form of everyday sentences and is generally an application of mathematical concepts learned.

RalphSchwarzkopf statesthat the question of the storyisaneed fortranslationbetween the realworld and mathematics, realworldgives aneverydayunderstandingof thestory.(Lia,2007) Based on the above understanding, it can be said that the story is a matter of math that is expressed orexpressed withwords orsentences in the form of stories associated with daily life. According to Hamzah (2014) the story has the following characteristics: the question in this form is a description that contains one / some mathematical concepts so that students are assigned to detail the concepts contained in the story of the story, generally the description of the problem is the application of mathematical concepts in life daily or real state or real world, so that students seem to face the real truth. Students are required to master the test material and can express it in written language is good and true. It is good to draw the connection between the knowledge that students already have with the material being considered. The steps in the ability to solve the problem of the story include: 1) Understanding the problem, which is the ability to determine what is known and asked in the matter, 2) Creating a strategy plan, namely the ability of students to create mathematical strategies from the given story, determining which formula should be used and associate the mathematical concepts needed to solve the problem of the story, 3) Complete the mathematical strategy, ie the ability of students to run mathematical strategies by performing the correct counting operations, so as to get the solution of the problem, 4) Interpreting the mathematical strategy, calculate from mathematical strategy with mathematical sentence to determine answer of story problem. To note in the implementation of learning in solving this problem is that students are able to understand the process and procedures, so that students skillfully determine and identify relevant conditions and data. With the ability of students in understanding this process also students are able to generalize the skills that have been owned. Finally, students will learn independently about the process of solving the problem. (Lia, 2007). 


\section{RESEARCH METHODS}

The research method used by researchers is Classroom Action

Research (PTK). Classroom action research is a type of action research conducted by teachers in the classroom. (Abdul Rozak, 2014) The essence of classroom action research is the variety of classroom contextual teaching research conducted by the teacher to solve the learning problems faced by the teacher, improve the quality and learning outcomes and try out new learning things for the quality improvement and learning outcomes. Sanjaya (2009). The purpose of TOD is to improve and improve the practice of learning, improving the professional services of teachers in handling the learning process. In principle this classroom action research uses several cycles, where each cycle includes four stages: Planning (Planning), acting, observing, and reflecting. Samsu (2013). If at the end of the cycle has been known the location of success or obstacles of action in the previous cycle then the researchers determine the design for the next cycle. Here's an explanation of each of the stages in classroom action research. 1) Planning (Planning), the initial stage in classroom action research is planning, in this stage the researcher identifies the problem of the student's learning process of mathematics. To obtain accurate information, researchers conducted interviews with teachers of the field of study to find out various obstacles encountered during the process of learning mathematics in the classroom. Furthermore, the researcher plan the appropriate action based on the cause of the learning problem by preparing the learning plan and the student worksheet, allocating time according to the learning steps, preparing the research instrument, 2) Acting, this stage is the implementation or application of the contents of the design or can also be referred to as the core activity of classroom action research. The study takes the learning action by applying the learning model of Discovery Learning (DL) in each cycle after that at the end of the cycle is conducted test and interviewing the students, 3) Observation, observation is a follow-up of the implementation which has been done, teachers can find the problems that occur in the classroom and can immediately determine the next step as a solution to improve the learning process so that the next meeting will be easy to achieve the expected goal. Nuri (2014).

The observation stage is carried out simultaneously with the implementation of the action. At this stage the researcher is assisted by an observer in observing and documenting all the things happening in the process of implementation of action during learning. This is done in order to obtain clear data for improvement in the next cycle, 4) Reflection (Reflecting), this stage is the final stage in the cycle, which is an activity to analyze the results obtained during the cycle stage. Researchers look back and reflect on what has been done during the learning process and its impact on the learning process of students. With this reflection, the teacher will find out what mistakes the teacher has made to impact student actions and minimize the same mistakes in later learning. After a reflection may appear new things or new problems are more complex, so it needs to be done planning, action, observation, and re-reflection. At this stage, the analysis is done by the researchers together with the observer so it can be known whether the activities implemented have achieved the expected success indicator or still need improvement. If there is a problem of the reflection process then a review will be done through the next cycle. 


\section{RESULTS AND DISCUSSION}

The ability to solve student story problems can be known from the four indicators used in this study. The indicators are understanding the problem, planning the settlement, solving the problem and summarizing the truth of the answer. After the learning process with the Discovery Learning model during cycle I and cycle II, obtained data about the average score of ability to solve the problem of students' stories. Comparison of test results of cycle I and cycle II seen from each indicator that can be known from Figure 1.

\section{Figure 1}

Comparison of Scores Solving Problems of Cycle I and Cycle II. The picture above shows that in the first cycle students more controlled indicators understand the problem and choose a strategy. In the indicator of running the strategy and conclude the answer students can not do it. The right is because students are less careful in solving the problem with the strategy chosen on the story so there are still many mistakes made by students when answering questions. Most students also did not re-examine the results of the answers, so students did not deduce the answers from the given story. In cycleII students have mastered the indicators understand the problem, choose the strategy, solve theproblemand conclude theanswer.IncycleIIhas asignificantincreaseineachindicator of ability to solve the story problem. Students are able to understand and interpretinformation into the language of mathematics and solve problems by involving mathematical strategies. Based on the above interpretation can be concluded that the ability to solve the problem of students' stories increased from cycle I to cycle II on sema indicator ability to solve the story problem. This shows the success of the action given in cycle II. Descriptive statistics of the ability test data to solve the problems in cycles I and II are presented in table 2.

Table 2

\begin{tabular}{|ll|l|}
\hline \multicolumn{1}{|c|}{$\begin{array}{c}\text { Descriptive } \\
\text { Statistic }\end{array}$} & Cycle I & Cycle II \\
\hline Average & 68,6 & 83,5 \\
\hline $\begin{array}{l}\text { S t a n d a r d } \\
\text { Deviation }\end{array}$ & 12,8 & 10,15 \\
\hline
\end{tabular}

The ability to solve student story problems in cycle I obtained an average of 68.6 and a standard deviation of 12.8 . With the average value and standard deviation of this shows that the ability to solve the problem of students' stories has not been maximal and not evenly distributed, the student's score is still heterogeneous. This means that there is still a difference in value that is too high between students with one student the other. Hi is also reinforced with a range of large enough data values that is where the largest value of 90 and the smallest 30. Furthermore, in cycle II there is an increase in the average score of ability to solve the problem of students' stories to be 83.5 and standard deviation in cycle II becomes smaller 10.15. This indicates that the student's value is homogeneous, meaning there is no difference in value is too high, seen from the test results of cycle II the largest value of 100 and the smallest value 60 . This shows that the ability to solve the problem of students' stories evenly compared from cycle I. 


\section{CONCLUSION}

Learning planning using discovery learning model should be prepared in detail, both with respect to teaching materials, learning activities, media and learning tools and evaluation of learning. It is intended that teachers or researchers really ready to carry out the learning process in accordance with the planned. Implementation of learning by using the model of discovery learning makes students more enthusiastic in receiving lessons. This happens because students learn from experience directly so that what they gain during learning they understand more. Activities and abilities of students in solving math story problems during the learning process gradually undergo significant changes, students become more active in following the learning activities, actively asked and answered and more skilled in communicating. Mathematics learning with Discovery Learning model can improve the ability to solve students' story problem in SDI Al-Kautsar Bintaro. It is shown that during the learning process with the Discovery Learning model is more optimal in improving the ability to solve the student story problem, with the average score of students' mathematical representation ability at the end of the first cycle of 68.6 with the number of students who reach KKM 14 students and the highest score 90 In the second cycle increased to 83.5 with the number of students reached KKM 19 students with the highest score of 100 as many as 5 students.

\section{REFERENCES}

Anisa, Nuri. “ Penerapan Metode Inkuiri untuk Meningkatkan Aktivitas dan Hasil Belajar Siswa Pada Mata Pelajaran Ilmu Pengetahuan Alam (IPA) Penelitian Tindakan Kelas pada Siswa Kelas V SDN Barunagri, Lembang", Tarbiya: Journal of Education In Muslim Society, vol. 1, No. 2, 5 Desember 2014.

Cahyo, Agus N. Panduan Aplikasi Teori-Teori Belajar Mengajar Teraktual dan Terpopuler. Yogyakarta: DIVA Press. 2013.

Hamzah, Ali dan Muhlisrarini. Perencanaan dan Strategi Pembelajaran Matematika. Jakarta: PT Raja Grafindo Persada. 2014.

Kurniawati, Lia. "Pendekatan Pemecahan Masalah (Problem Solving) dalam Upaya Mengatasi Kesulitan-Kesulitan Siswa pada Soal Cerita": Pendekatan Baru dalam Proses Pembelajaran Matematika dan Sains Dasar. Jakarta: PIC UIN. 2007.

Raharjo, Marsudi dkk. Modul Matematika SD Program bermutu Pembelajaran Soal Cerita di SD. Sleman: PPPPTK. 2009.

Rahman, Risqi dan Samsul Maarif. "Pengaruh Penggunaan Metode Discovery Terhadap Kemampuan Analogi Matematis Siswa SMK Al-Ikhsan Pamarican Kabupaten Ciamis Jawa Barat", Jurnal Prodi Matematika STKIP Siliwangi Bandung, Vol. 3, Nomor 1, Febuari 2014.

Ridwanudin, Dindin. Bahasa Indonesia. Jakarta: UIN Press. 2015. Rozak, Abd. dan Maifalinda Fatra. Bahan Pelatihan Penelitian Tindak Kelas. Jakarta: FITK UIN Jakarta. 2014.

Sanjaya, Wina. Penelitian Tindak Kelas. Jakarta: Kencana. 2009. 
Slavin, Robert E. Psikologi Pendidikan Teori dan Praktik. Jakarta: PT Indeks. 2011.

Sumadayo, Samsu. Penelitian Tindakan Kelas. Yogyakarta: Graha Ilmu. 2013.

Susanto, Ahmad. Teori Belajar dan Pembelajaran di Sekolah Dasar. Jakarta: Kencana. 2013.

Trianto. Mendesai Model Pembelajaran Inofatif-Progresif. Jakarta: Kencana. 2015.

Winarni, Endang Setyo dan Sri Harmini. Matematika untuk PGSD. Bandung: PT Remaja Rosdakarya. 2011. 